\title{
Pengaruh Senam Rematik terhadap Perubahan Skala Nyeri pada Lanjut Usia dengan Osteoarthritis Lutut
}

\author{
Vivi Meliana Sitinjak ${ }^{1}$, Maria Fudji Hastuti ${ }^{2}$, Arina Nurfianti ${ }^{3}$ \\ ${ }^{1}$ Mahasiswa Program Studi Keperawatan Universitas Tanjungpura Pontianak \\ ${ }^{2}$ Perawat Rumah Sakit Universitas Tanjungpura, ${ }^{3}$ Dosen Pengajar Universitas Tanjungpura \\ Email:vsitinjak86@gmail.com
}

\begin{abstract}
Abstrak
Proses degeneratif tubuh yang terjadi seiring dengan pertambahan usia akan meningkatkan risiko terjadinya nyeri sendi akibat osteoarthritis lutut, terutama pada lansia. Nyeri sendi yang dialami akan menurunkan aktivitas fisik lansia dan berdampak pada penurunan lingkup gerak sendi. Salah satu tindakan nonfarmakologi yang dapat digunakan untuk mengurangi skala nyeri sendi adalah senam rematik. Gerakan aktif dan ringan tanpa menggunakan beban dalam senam rematik menjadi pemicu pengeluaran beta-endorfin, neuromudulator alami tubuh yang dapat menghambat pelepasan impuls nyeri sehingga skala nyeri sendi lansia berkurang. Tujuan penelitian ini untuk mengetahui pengaruh senam rematik terhadap perubahan skala nyeri pada lansia dengan osteoarthritis lutut. Desain penelitian quasi experimental dengan pendekatan pretest-posttest with control group design. Responden dipilih menggunakan teknik purposive sampling di Panti Werdha Sinar Abadi Kota Singkawang kemudian dibagi menjadi kelompok perlakuan dan kelompok kontrol. Instrumen penelitian adalah Pain Assessment in Advanced Dementia Scale dengan analisis data menggunakan Paired T Test dan Independent T Test.Uji hipotesis dengan Paired T Test pada kelompok perlakuan $p$-value $=0,000$ dan pada kelompok kontrol $p$-value $=0,017$. $P$-value kedua kelompok $<0,05$ yang berarti terdapat penurunan skala nyeri setelah pemberian senam rematik pada kelompok perlakuan dan kelompok kontrol. Uji beda mean posttest antara kelompok perlakuan dan kelompok kontrol menggunakan Independent T Test menunjukkan $p$-value $=0,000(\mathrm{p}<0,05)$ yang berarti penurunan skala nyeri dengan senam rematik lebih bermakna daripada penurunan skala nyeri yang tidak diberikan senam rematik. Terdapat pengaruh senam rematik terhadap perubahan skala nyeri pada lansia dengan osteoarthritis lutut berupa penurunan skala nyeri pada kelompok perlakuan dan kelompok kontrol, tetapi hasil uji beda mean kedua kelompok menunjukkan adanya perbedaan perubahan skala nyeri, skala nyeri kelompok perlakuan lebih rendah daripada kelompok kontrol. Penurunan skala nyeri lebih efektif pada kelompok menggunakan senam rematik daripada kelompok yang tidak diberikan senam rematik.
\end{abstract}

Kata kunci: Lansia, nyeri sendi, osteoarthritis lutut, senam rematik, skala nyeri.

\section{The Effect of Rheumatoid Physical Exercises to Reduce Pain Intensity among Elderly Diagnosed with Knee Osteoarthritis}

\begin{abstract}
It is known that arthritis pain can reduce physical activities and join mobility among elderly. A rheumatoid physical exercise is considered as one of non-pharmacologic treatment to minimise their pain intensity. This activity stimulates the release of beta endorphin which inhibits pain impulse modulation that contributed to the reduction of pain intensity. This study aimed to examine the effect of structured physical exercises towards pain intensity among knee osteoarthritis. A quasi experimental with pretest-posttest with control group design was designed. Two groups of elderly were assigned in control and intervention groups. Respondent were recruited using purposive sampling from Panti Werdha Sinar Abadi in Singkawang Kalimantan. Data was assessed using Pain Assessment in Advanced Dementia Scale and then analysed by employing Paired T-test and Independent T-test. Findings indicated there was a different of pain intensity within the intervention group ( $p$-value $=0,000)$ and controlled group $(p$-value $=0,017)$. Thus, the reduction of pain score was more effective among the intervention group compared to the controlled group.
\end{abstract}

Keywords: Arthritis pain, elderly, knee osteoarthritis, rheumatoid physical exercise, pain scale. 
Vivi Meliana Sitinjak : Pengaruh Senam Rematik terhadap Perubahan Skala nyeri

\section{Pendahuluan}

Peningkatan populasi lanjut usia di dunia saat ini sejalan dengan peningkatan jumlah kasus nyeri sendi (Eliopoulus, 2013). Pada sensus penduduk Indonesia tahun 2010, jumlah lansia tercatat sebanyak 18,1 juta penduduk lansia dan diperkirakan akan meningkat 10 tahun mendatang sebesar 60\% (Badan Pusat Statistik Indonesia, 2015). Hasil survey badan kesehatan dunia World Health Organization (WHO) mengatakan bahwa jumlah lansia Indonesia pada tahun 2010 tersebut sudah menduduki sebesar 9,77\% dari jumlah total penduduk Indonesia. Hal ini membuktikan bahwa perkembangan jumlah lansia di Indonesia sangat pesat dan diperkirakan pada abad ke-21 ini akan terjadi peningkatan jumlah penduduk usia tua atau Era Of Population Aging dimana jumlah penduduk lansia di Indonesia akan meningkat dengan cepat dan secara potensial dapat menimbulkan permasalahan yang memengaruhi kelompok penduduk lainnya (Hardywinoto, 2005). Menua (aging) merupakan suatu proses menghilangnya secara perlahan-lahan kemampuan jaringan untuk memperbaiki diri atau mengganti diri dan mempertahankan struktur dan fungsi normalnya (Stanley, 2007). Proses penuaan ditandai dengan perubahan fisiologis yang terjadi pada beberapa organ dan sistem. Perubahan yang terjadi menyebabkan penurunan fungsi tubuh untuk melakukan aktivitas. Seiring dengan peningkatan persentase lansia terjadi juga peningkatan jumlah dan tingkat kejadian penyakit kronis yang disebabkan oleh penurunan kemampuan tubuh untuk beradaptasi dengan stres lingkungan serta kelemahan pada lansia. (Efendi \& Makhfudli, 2009). Tujuh golongan penyakit yang banyak dilaporkan terjadi pada lansia adalah arthritis, hipertensi, gangguan pendengaran, kelainan jantung, sinusitis kronik, penurunan visus, dan gangguan pada tulang (Stanley, 2007).

Masalah muskuloskeletal seperti arthritis dan gangguan pada tulang menjadi masalah yang sering terjadi pada lansia karena memengaruhi mobilitas dan aktivitas yang merupakan hal vital bagi kesehatan total lansia. Arthritis dan gangguan pada tulang menyebabkan munculnya nyeri sendi. Nyeri sendi merupakan nyeri yang dirasakan di bagian persendian dan sekitarnya akibat proses inflamasi maupun terjadi secara idiopatik (Yatim, 2006). Nyeri sendi memiliki prevalensi nyeri muskuloskeletal yang paling banyak terjadi pada lansia. Fenomena ini terjadi karena lanjut usia merupakan usia yang paling rentan terkait dengan disabilitas dan perubahan degeneratif (Hardywinoto, 2005). Nyeri sendi merupakan pengalaman subjektif yang dapat memengaruhi kualitas hidup lansia termasuk gangguan aktivitas fungsional lansia (Nurhidayah, 2012). Penurunan aktivitas fungsional lansia menyebabkan penurunan lingkup gerak sendi (LGS) (Mirza, 2012). LGS merupakan gerakan pada bagian tubuh yang dilakukan oleh otot-otot yang menggerakkan tulang-tulang pada persendian dalam berbagai pola dan rentang gerak. Kekuatan otototot merupakan kekuatan yang berasal dari luar. Untuk mempertahankan LGS sendi pada keadaan normal, otot harus digerakkan secara optimal dan teratur. Aktivitas LGS juga dianjurkan sebagai terapi yang dapat mempertahankan pergerakan sendi dan jaringan lunak, mempertahankan pergerakan sendi dan jaringan lunak, serta meminimalkan kontraktur (Santoso, 2009).

Salah satu faktor pencetus nyeri sendi adalah osteoarthritis (OA) karena nyeri sendi merupakan keluhan utama yang muncul pada penderita OA (Felson \& Schaible, 2010). OA merupakan salah satu jenis penyakit rematik yang paling banyak ditemukan pada golongan usia lanjut di lndonesia, berkisar 50-60\% (Muchid dkk., 2006). Nyeri sendi muncul dengan adanya hambatan pada sendi saat dilakukan gerakan. Data dari World Health Organization (2011) menunjukkan jumlah penderita OA di seluruh dunia sebanyak 151 juta jiwa. Di kawasan Asia Tenggara kejadian OA mencapai 24 juta jiwa dan untuk wilayah Indonesia sekitar 100\% laki-laki dan perempuan di Indonesia dengan usia diatas 75 tahun mempunyai gejala-gejala OA (Arden $\&$ Nevitt, 2006). OA dapat menyerang semua sendi, predileksi yang tersering adalah pada sendi-sendi yang menanggung beban berat badan seperti panggul, lutut, dan sendi tulang belakang bagian lumbal bawah. Lokasi OA yang sering ditemukan adalah pada lokasi lutut (Arissa, 2013). Lokasi penemuan kejadian OA serupa dengan laporan data Riskesdas yang menyatakan bahwa lokasi terbanyak 
Vivi Meliana Sitinjak : Pengaruh Senam Rematik terhadap Perubahan Skala nyeri

terjadinya OA adalah pada sendi lutut yang mencapai 89,91\% (Riskesdas, 2013).

Dengan keberadaan nyeri akibat OA lutut ini, lansia yang menderita kemudian membatasi pergerakan pada bagian yang nyeri sehingga luas gerak sendi ke semua arah berkurang. Bila gerakan pasif lebih dominan dari pada gerakan aktif dapat menyebabkan kekakuan dan gangguan pada otot sendi (Isbagio, 2005). Nyeri dan kaku sendi yang bertahan lama dapat menghentikan secara permanen fungsional sendi. Penghentian fungsional sendi ini dapat membatasi aktivitas fisik lansia, selanjutnya lansia mengalami penurunan dari quality of life (Hopman-Rock et al., 2007). Kurang aktifitas fisik merupakan faktor risiko timbulnya berbagai penyakit pada populasi lansia, sementara itu jika terdapat peningkatan aktifitas fisik pada lansia dapat meningkatkan kesehatan, meningkatkan quality of life, serta menurunkan morbiditas dan mortalitas (Klieman et al.,2011).

Menurut penelitian Nelson et al.,(2010), mempertahankan aktivitas pergerakan sendi sangat dianjurkan untuk meminimalkan kontraktur dan mengatasi penurunan fungsional sendi akibat nyeri sendi yang muncul. Tindakan pertahanan yang dapat dilakukan untuk mengurangi nyeri agar sendi mampu difungsikan berdasarkan Muchid dkk., (2006) adalah secara farmakologis atau tindakan pemberian obat-obatan, tindakan non farmakologis seperti edukasi pasien, terapi fisik, okupasional, aplikasi dingin atau panas, latihan fisik, istirahat dan merawat persendian, penurunan berat badan, akupunktur, dan terapi bedah sebagai pilihan terakhir. Jurnal publikasi American College Of Rheumatologi mengatakan terapi yang lebih direkomendasikan untuk OA lutut adalah terapi non farmakologis yang bersifat terapi modalitas seperti aerobik, latihan ketahanan, dan intervensi psikososial (Hochberg et al., 2012). Terapi non farmakologis lainnya dapat digunakan untuk menurunkan nyeri sendi tetapi tidak memberikan peningkatan pada kekuatan otot sendi karena peningkatan kekuatan otot sendi dapat dicapai dengan adanya pergerakan melalui aktivitas fisik. Terapi seperti penurunan berat badan, akupunktur, okupasional, dan aplikasi dingin atau panas membantu meringankan nyeri sendi tanpa memberi perubahan terhadap kondisi kekuatan otot-otot sendi.

Penelitian yang dilakukan tahun 2007 tentang tindakan non farmakologis berupa latihan fisik yang diberikan pada penderita arthritis terbukti berpengaruh dalam penurunan nyeri sendi dan memberikan efek positif dalam meningkatkan kekuatan sendi (Nauberger et al, 2007). Hasil tersebut sejalan dengan review penelitian yang mengatakan pasien OA lutut yang melaksanakan latihan fisik berupa aerobik ataupun latihan kekuatan otot di rumah dapat mengurangi nyeri dan disabilitas diri (Roddy, 2011). Penelitian Benefits of Physical Activity for Knee Osteoarthritis menyatakan dengan menjadi lebih aktif, orang dewasa tua dengan OA lutut dapat menurunkan rasa sakit mereka dan risiko gangguan fungsional atau cacat (Mentes, 2010).

Latihan yang diberikan kepada penderita OA lutut dapat berupa olahraga fisik. Olahraga fisik bertujuan untuk mempertahankan pergerakan sendi dan memiliki pengaruh besar dalam penurunan skala nyeri sendi (Stevenson et al, 2012). Nyeri sendi pada penderita OA termasuk dalam kategori nyeri somatik dalam dimana reseptor nyeri ini terletak pada otot dan tulang serta penyokong tubuh lainnya. Tubuh memiliki neuromodulator yang dapat menghambat transmisi impuls nyeri, salah satunya adalah beta-endorfin (Tamsuri, 2007). Endorfin berperan untuk mengurangi sensasi nyeri dengan memblokir proses pelepasan substansi $\mathrm{p}$ dari neuron sensorik sehingga proses transmisi impuls nyeri di medula spinalis menjadi terhambat dan sensasi nyeri menjadi berkurang (Price \& Wilson, 2005). Tingginya beta-endorfin juga memiliki dampak psikologis langsung yakni membantu memberi perasaan santai, mengurangi ketegangan, meningkatkan perasaan senang, membuat seseorang menjadi lebih nyaman, dan melancarkan pengiriman oksigen ke otot (Nursalam, 2007). Menurut Arthritis Care and Research olahraga dapat menstimulasi meningkatnya pelepasan hormon endorfin. Para peneliti menemukan bahwa olahraga tiga kali seminggu secara signifikan memperbaiki kesehatan pasien-pasien arthritis termasuk OA (Stevenson et al., 2012). Oleh karena pemberian terapi farmakologis memiliki risiko tinggi menghasilkan efek yang kurang baik bagi kesehatan lansia dengan berbagai penurunan fungsi tubuh maka terapi non 
Vivi Meliana Sitinjak : Pengaruh Senam Rematik terhadap Perubahan Skala nyeri

farmakologis seperti pemberian aktivitas olahraga fisik ini menjadi alternatif terbaik untuk mengatasi nyeri lansia (Capezuti, 2008).

Salah satu dari olahraga fisik yang sederhana dan mudah dilakukan adalah senam rematik (Nurhidayah, 2012). Senam rematik merupakan senam yang befokus pada mempertahankan lingkup gerak sendi secara maksimal. Tujuan dari senam rematik ini yaitu mengurangi nyeri sendi dan menjaga kesehatan jasmani penderita rematik. Keuntungan lain dari senam rematik yaitu tulang menjadi lebih lentur, otot tetap kencang, memperlancar peredaran darah, menjaga kadar lemak darah tetap normal, tidak mudah mengalami cidera, dan kecepatan reaksi sel tubuh menjadi lebih baik (Heri, 2014).

Berdasarkan studi pendahuluan yang telah peneliti lakukan di Panti Werdha Sinar Abadi Kota Singkawang didapatkan 25 orang lansia mengalami nyeri sendi OA pada area lutut dengan skala nyeri sedang sampai skala nyeri berat. Lansia yang diwawancarai belum melakukan penatalaksanaan nyeri sendi secara khusus untuk mengatasi nyeri, lansia cenderung membiarkan nyeri yang dia rasakan. Belum ada program khusus untuk menurunkan nyeri sendi yang dilakukan oleh petugas kesehatan panti werdha. Penanganan nyeri yang diberikan terhadap nyeri berat adalah dengan pemberian obat anti nyeri.

Pada hasil pendataan lansia di panti werdha, sebesar $41,7 \%$ lansia tidak bersekolah dan mengaku tidak mengetahui informasi tentang penatalaksanaan nyeri. Pengetahuan diperlukan sebagai dukungan dalam memunculkan rasa percaya diri maupun sikap dan perilaku setiap hari manusia. Pengetahuan merupakan domain yang sangat penting untuk membentuk tindakan seseorang. Pada lansia kemampuan penerimaan atau mengingat suatu pengetahuan menjadi berkurang, selanjutnya pada usia lanjut intelegensi menurun sehingga menyebabkan kurangnya kemampuan dalam memahami suatu informasi dan pengetahuan umum (Widyastuti, 2008). Tingkat pengetahuan lansia yang rendah menimbulkan keterbatasan pengetahuan untuk mencegah, proteksi dini, dan penatalaksanaan nyeri sendi yang tepat guna meningkatkan derajat kesehatan lansia. Sampai saat ini, banyak yang tidak mengetahui cara melakukan dan manfaat melaksanakan senam rematik, termasuk tenaga kesehatan yang menangani banyak lansia di panti werdha ataupun wilayah kerja puskesmas dengan komunitas lansia. Berdasarkan hasil screening kegiatan di 5 puskesmas Kota Singkawang, program senam rematik ini jarang diberikan pada komunitas lansia bahkan belum dimasukkan dalam kegiatan rutin panti werdha dan posyandu lansia di wilayah kerja puskesmas. Kegiatan pengenalan dan promosi kesehatan tentang senam rematik menjadi isu penting yang dapat diterapkan oleh perawat sebagai care giver dalam memberikan pelayanan pencegahan dan penatalaksanaan osteoarthritis lutut untuk meningkatkan derajat kesehatan hidup lansia.

\section{Metode Penelitian}

Penelitian ini menggunakan desain quasi experimental dengan pendekatan pretest and posttest with control group design. Populasi terbagi menjadi populasi target dan populasi terjangkau.Populasi target dalam penelitian ini adalah lansia dengan nyeri sendi akibat osteoarthritis lutut. Populasi terjangkau dalam penelitian ini adalah semua lanjut usia yang mengalami nyeri sendi osteoarthritis di Panti Werdha Sinar Abadi Singkawang sejumlah 35 orang.

Teknik sampling dalam penelitian ini menggunakan non probability sampling dengan teknik purposive sampling. Peneliti memilih sampel berdasarkan kriteria sampel dan sampel yang dipilih memiliki informasi yang diperlukan untuk penelitian.Kriteria inklusi merupakan lansia penghuni panti werdha sinar abadi Kota Singkawang lansia dengan usia $>55$ tahun, memiliki riwayat medis osteoarthritis lutut, dan keluhan nyeri sendi (skala 1-9). Kriteria eksklusinya adalah lansia yang mengalami radang dengan skala nyeri sendi berat tidak terkontrol (skala 10) yang mengharuskan lansia untuk bedrest. Pada penelitian ini jumlah responden yang digunakan sebanyak 24 orang responden yang dibagi menjadi 12 orang responden kelompok perlakuan dan 12 orang responden kelompok kontrol, pembagian kelompok dilakukan dengan cara simple random sampling yaitu menggunakan nomor undian secara acak 
Vivi Meliana Sitinjak : Pengaruh Senam Rematik terhadap Perubahan Skala nyeri

dilakukan oleh peneliti.

Tempat penelitian dilaksanakan di Panti Werdha Sinar Abadi Kota Singkawang. Waktu penelitian selama 2 minggu pada periode Januari sampai Februari 2016. Variabel yang memengaruhi atau variabel independen dalam penelitian ini adalah senam rematik sedangkan variabel terpengaruh atau variabel dependen dalam penelitian ini adalah skala nyeri sendi pada lansia di Panti Werdha Sinar Abadi Singkawang. Alat yang digunakan adalah hand bandle dan kursi, untuk alat ukur untuk mengobservasi tingkat nyeri sendi yang digunakan dalam penelitian adalah lembar observasi skala nyeri sendi Pain Assessment in Advanced Dementia Scale (PAINAD) karena berdasarkan uji validitas instrumen yang dilakukan oleh DeWaters et al. (2008), mengatakan bahwa instrumen ini dapat digunakan untuk mengidentifikasi nyeri yang telah terjadi dalam jangka waktu yang lama seperti pada pasien dengan keluhan nyeri yang kronis pada lansia dengan gangguan kognitif ataupun lansia dengan kondisi kognitif yang utuh. Lembar observasi diisi oleh peneliti karena komponen lembar observasi hanya dapat dilihat dan disesuaikan oleh peneliti berdasarkan tanda dan gejala serta pemeriksaan fisik yang dilakukan terhadap lansia sehingga tidak diperlukan penerjemahan untuk lembar observasi tersebut, selain itu PAINAD juga belum memiliki hasil terjemahan bahasa Indonesia sehingga diragukan keakuratan data yang diperoleh jika diterjemahkan.

Peneliti mengambil sampel sesuai kriteria inklusi kepada 24 lansia, kemudian meminta informed concent. Selanjutnya pretest dilakukan pada kelompok perlakuan dan kelompok kontrol untuk menilai skala nyeri sendi sebelum perlakuan. Pada kelompok perlakuan dilakukan enam tahapan senam rematik selama 30 menit sebanyak 3 kali dalam seminggu selama dua minggu penelitian sedangkan pada kelompok kontrol hanya dilakukan pengkajian skala nyeri sendi. Pengaruh senam rematik terhadap perubahan skala nyeri sendi dianalisis dengan paired t test dan perbedaan antara kelompok perlakuan dan kelompok kontrol dianalisis dengan independent $t$ test. Penelitian ini telah mendapatkan izin penelitian dari komisi etik Fakultas Kedokteran Universitas Tanjungpura melalui surat keterangan lolos kaji etik atau ethical-clearance nomor 1611/UN22.9/ DT/2016 dan surat rekomendasi lolos kaji etik nomor 1613/UN22.9/DT/2016. Etika penelitian yang dilakukan berdasarkan Nursalam (2008) adalah dengan pemberian intervensi yang tidak mengakibatkan cedera kepada subjek. Jika intervensi penelitian berpotensi mengakibatkan cedera atau stres tambahan maka akan dihentikan. Partisipasi subjek dalam penelitian dihindarkan dari keadaan yang tidak menguntungkan dan tidak dipergunakan dalam hal-hal yang merugikan subjek dalam bentuk apapun. Dalam penelitian ini, peneliti juga tidak memaksa untuk menjadi subjek penelitian. Subjek yang setuju menjadi responden secara sukarela menandatangani informed consent kemudian peneliti memberikan penjelasan secara rinci tentang penelitian yang dilakukan dan bertanggung jawab jika sesuatu terjadi kepada subjek. Penelitian dilakukan secara jujur, hatihati, dan berperikemanusiaan. Lingkungan penelitian dikondisikan agar memenuhi prinsip keterbukaan yaitu kejelasan prosedur penelitian.

\section{Hasil Penelitian}

Penelitian telah dilaksanakan sejak bulan Januari sampai Februari 2016 di Panti Werdha Sinar Abadi Kota Singkawang. Karakteristik usia responden terbanyak pada kelompok perlakuan adalah kelompok umur 60-74 tahun yang memiliki persentase sebesar 58,3\%. Pada kelompok kontrol kelompok umur 6074 tahun juga menjadi usia mayoritas dengan persentase sebesar $66,7 \%$. Karakteristik jenis kelamin dalam penelitian ini merata antara kelompok perlakuan dan kelompok kontrol yaitu $41,7 \%$ laki-laki dan $58,3 \%$ perempuan. Jumlah total jenis kelamin perempuan dalam penelitian ini lebih mendominasi dengan jumlah 14 orang $(58,35)$. Latar belakang pendidikan terakhir dengan jumlah terbanyak pada kelompok perlakuan adalah SD yaitu 7 orang $(58,3 \%)$ sedangkan tingkat pendidikan terakhir terbanyak pada kelompok kontrol adalah tidak sekolah yaitu sebanyak 6 orang $(50 \%)$.

Skala nyeri pretest kelompok kontrol 
Vivi Meliana Sitinjak : Pengaruh Senam Rematik terhadap Perubahan Skala nyeri

Tabel 1 Karakteristik Responden Penelitian berdasarkan Kelompok Umur, Jenis Kelamin, dan Tingkat Pendidikan

\begin{tabular}{llccccc}
\hline \multicolumn{1}{c}{$\begin{array}{c}\text { Karakteristik } \\
\text { Responden }\end{array}$} & $\begin{array}{c}\text { Perlakuan } \\
(\mathbf{n = 1 2})\end{array}$ & F & \multicolumn{2}{c}{$\begin{array}{c}\text { Kontrol } \\
(\mathbf{n}=\mathbf{1 2})\end{array}$} & \multicolumn{2}{c}{$\begin{array}{c}\text { Total } \\
(\mathbf{n}=\mathbf{2 4})\end{array}$} \\
\cline { 2 - 7 } & $\mathbf{F}$ & $\mathbf{\%}$ & $\mathbf{F}$ & $\mathbf{\%}$ & $\mathbf{F}$ & $\mathbf{\%}$ \\
\hline Kelompok Umur & & & & & & \\
60-74 tahun & 8 & 66,7 & 9 & 75,0 & 17 & 70,8 \\
75-90 tahun & 4 & 33,3 & 3 & 25,0 & 7 & 29,2 \\
Jenis Kelamin & & & & & & \\
Laki-laki & 5 & 41,7 & 5 & 41,7 & 10 & 41,7 \\
Perempuan & 7 & 58,3 & 7 & 58,3 & 14 & 58,3 \\
Tingkat Pendidikan & & & & & & \\
Tidak Sekolah & 4 & 33,3 & 6 & 50,0 & 10 & 41,7 \\
Tidak Tamat SD & 1 & 8,3 & 0 & 0 & 1 & 4,2 \\
SD & 7 & 58,3 & 6 & 50,0 & 13 & 54,2 \\
\hline
\end{tabular}

Tabel 2 Karakteristik Skala Nyeri Sendi Sebelum dan Sesudah Dilakukan Senam Rematik pada Kelompok Kontrol

\begin{tabular}{lcccc}
\hline & \multicolumn{2}{c}{$\begin{array}{c}\text { Pretest Kontrol } \\
\text { (n=12) }\end{array}$} & \multicolumn{2}{c}{$\begin{array}{c}\text { Posttest Kontrol } \\
\text { Skala) }\end{array}$} \\
\cline { 2 - 5 } & F & $\mathbf{\%}$ & F & $\mathbf{\%}$ \\
\hline Nyeri Ringan (1-3) & 0 & 0 & 0 & 0 \\
Nyeri Sedang (4-6) & 3 & 25 & 5 & 41,7 \\
Nyeri Berat Terkontrol & 9 & 75 & 7 & 58,3 \\
$(7-9)$ & & & & 100 \\
Total & 12 & 100 & 12 & \\
\hline
\end{tabular}

memiliki persentase sebesar $75 \%$ pada nyeri berat terkontrol (rentang skala nyeri 7-9) dan sebesar $25 \%$ pada nyeri sedang (rentang skala nyeri 4-6). Skala nyeri posttest pada kelompok kontrol yang mengalami nyeri berat terkontrol sebanyak 7 orang $(58,3 \%)$ dan mengalami nyeri sedang sebanyak 5 orang $(41,7 \%)$.

Skala nyeri pretest kelompok perlakuan sebesar $75 \%$ pada nyeri berat terkontrol (rentang skala nyeri 7-9) dan sebesar 25\% pada nyeri sedang (rentang skala nyeri 4-6). Pada skala nyeri sesudah senam rematik (Skala nyeri posttest), kelompok perlakuan mengalami nyeri sedang sebanyak 11 orang $(91,7 \%)$ dan mengalami nyeri ringan 1 orang $(8,3 \%)$.

Berdasarkan tabel 4 diperoleh nilai mean perubahan skala nyeri sendi pada kelompok perlakuan $(2,167)$ lebih besar dari pada kelompok kontrol $(0,417)$. Hasil uji hipotesis diperoleh $p$ value kelompok perlakuan sebesar 0,000 dan $p$ value kelompok kontrol sebesar 0,017 ,yang berarti terdapat perubahan skala nyeri sendi sebelum dan sesudah intervensi senam rematik pada kedua kelompok. Pada kelompok perlakuan $p$ value sebesar 0,000 menunjukkan bahwa korelasi antara mean skala nyeri sendi sebelum dan sesudah intervensi dengan senam rematik adalah kuat dan signifikan. Dengan demikian hipotesis yang menyatakan ada pengaruh pemberian senam rematik terhadap perubahan skala nyeri sendi pada lansia dengan OA lutut terbukti dengan adanya perubahan skala nyeri yang signifikan sesudah pemberian senam rematik. Perubahan yang terjadi pada skala nyeri sendi lansia yaitu penurunan skala nyeri sendi.

Berdasarkan tabel 5 diperoleh nilai 
Vivi Meliana Sitinjak : Pengaruh Senam Rematik terhadap Perubahan Skala nyeri

Tabel 3 Karakteristik Skala Nyeri Sendi Sebelum dan Sesudah Dilakukan Senam Rematik pada Kelompok Perlakuan

\begin{tabular}{lcccc}
\hline & \multicolumn{2}{c}{$\begin{array}{c}\text { Pretest Kontrol } \\
\text { (n=12) }\end{array}$} & \multicolumn{2}{c}{$\begin{array}{c}\text { Posttest Kontrol } \\
(\mathbf{n}=\mathbf{1 2})\end{array}$} \\
\cline { 2 - 5 } Skala Nyeri & F & $\mathbf{\%}$ & $\mathbf{F}$ & $\mathbf{\%}$ \\
\hline Nyeri Ringan (1-3) & 0 & 0 & 1 & 8,3 \\
Nyeri Sedang (4-6) & 3 & 25 & 11 & 91,7 \\
Nyeri Berat Terkontrol & 9 & 75 & 0 & 0 \\
$(7-9)$ & 12 & 100 & 12 & 100 \\
Total & & & & \\
\hline
\end{tabular}

Tabel 4 Pengaruh Senam Rematik Sebelum dan Sesudah Intervensi

\begin{tabular}{|c|c|c|c|c|c|c|c|c|c|c|c|}
\hline \multirow[t]{2}{*}{$\begin{array}{c}\text { Paired } \\
\text { Test }\end{array}$} & \multicolumn{5}{|c|}{$\begin{array}{c}\text { Skala Nyeri Sendi } \\
\text { Pretest }\end{array}$} & \multicolumn{4}{|c|}{$\begin{array}{c}\text { Skala Nyeri Sendi } \\
\text { Posttest }\end{array}$} & \multirow{2}{*}{$\begin{array}{c}\begin{array}{c}\Delta \text { Skala } \\
\text { Nyeri } \\
\text { Sendi }\end{array} \\
\text { SD }\end{array}$} & \multirow[t]{2}{*}{ p-value } \\
\hline & Mean & SD & Min & Max & Mean & SD & Min & Max & Mean & & \\
\hline $\begin{array}{l}\text { Perlakuan } \\
(\mathrm{n}=12)\end{array}$ & 7,08 & 0,900 & 6 & 9 & 4,92 & 0,966 & 3 & 6 & 2,167 & 0,937 & 0,000 \\
\hline $\begin{array}{l}\text { Kontrol } \\
(\mathrm{n}=12)\end{array}$ & 7,00 & 0,953 & 5 & 8 & 6,58 & 0,793 & 5 & 8 & 0,417 & 0,515 & 0,017 \\
\hline
\end{tabular}

Tabel 5 Uji Beda Mean Skala Nyeri Sendi pada 2 Kelompok Berbeda

\begin{tabular}{lccccc}
\hline Independent T Test & \multicolumn{2}{c}{$\begin{array}{c}\text { Perlakuan } \\
(\mathbf{n}=\mathbf{1 2})\end{array}$} & \multicolumn{2}{c}{$\begin{array}{c}\text { Kontrol } \\
(\mathbf{n}=\mathbf{1 2})\end{array}$} & p-value \\
& Mean & SD & Mean & SD & \\
\cline { 2 - 5 } & 7,08 & 0,900 & 7,00 & 0,953 & 0,828 \\
Skala Nyeri Pretest & 4,92 & 0,996 & 6,58 & 0,793 & 0,000 \\
Skala Nyeri Posttest & & & & &
\end{tabular}

signifikansi posttest antara kedua kelompok sebesar $0,000(\mathrm{p}<0,05)$ yang berarti terdapat perbedaan skala nyeri posttest antara kelompok perlakuan dan kelompok kontrol. Hasil uji data menunjukkan bahwa mean skala nyeri posttest kelompok dengan perlakuan lebih rendah yaitu 4,92 daripada mean skala nyeri posttest kelompok kontrol yaitu 6,58. Kelompok dengan intervensi senam rematik memberikan penurunan skala nyeri sendi yang lebih signifikan daripada kelompok tanpa intervensi senam rematik dengan $p$ value sebesar $0,000(\mathrm{p}<0,05)$ menunjukkan bahwa ada perbedaan yang signifikan antara kelompok perlakuan yang diberikan intervensi senam rematik dengan kelompok kontrol yang tidak diberikan senam rematik. Perubahan skala nyeri sendi berupa penurunan skala nyeri sendi lebih efektif ditunjukkan oleh kelompok perlakuan dengan senam rematik daripada kelompok kontrol tanpa senam rematik.

\section{Pembahasan}

Berdasarkan sebaran karakteristik responden penelitian, beberapa faktor terbukti memengaruhi munculnya nyeri sendi akibat OA lutut. Beberapa faktor tersebut meliputi usia, jenis kelamin, dan tingkat pendidikan. Distribusi usia responden yang berada pada rentang 60-74 tahun atau lanjut usia dalam penelitian ini dapat membuktikan kebenaran teori yang menyatakan bahwa OA lutut 
Vivi Meliana Sitinjak : Pengaruh Senam Rematik terhadap Perubahan Skala nyeri

yang menyebabkan terjadinya nyeri sendi disebabkan oleh proses degeneratif (Muslihah, 2014). Hasil ini didukung oleh penelitian Maharani (2010) yang mengatakan bahwa usia >50 tahun akan memiliki persentase lebih besar terhadap kejadian osteoarthritis. Penelitian Khairani (2012) juga mendukung hasil penelitian bahwa usia penderita osteoarthritis paling sering pada usia diatas 60 tahun dan tidak pernah terjadi pada anakanak dikarenakan kondisi tulang rawan yang memiliki keterbatasan dalam proses regenerasi. Menurut Litwic et al., (2013), osteoarthritis merupakan penyakit yang ireversibel dan kemungkinan terjadi serta prevalensinya meningkat secara tidak terhingga seiring dengan peningkatan usia. Proses degeneratif danketerbatasan kemampuan tubuh untuk terus mempertahankan regenerasi sel menjadi faktor penyebab nyeri sendi OA lutut dipengaruhi oleh usia, selain itu, di penghujung usia akan terjadi penurunan kapasitas anabolisme yang berakibat pada menurunnya kapasitas regenerasi dari kondrosit yang merupakan satu-satunya sel penyusun matriks kartilago, hal inilah yang menjadi faktor penyebab nyeri sendi OA lutut dipengaruhi oleh usia.

Jenis kelamin perempuan merupakan faktor resiko terjadinya osteoarthritis (OA), terutama OA lutut. Menurut penelitian Roman-Blas et al., (2013), jenis kelamin perempuan meningkatkan risiko kejadian OA lutut sebesar 1,84 kali. Prevalensi OA lutut meningkat signifikan pada wanita usia> 55 tahun saat dimana onset menopause dimulai pada kebanyakan perempuan. Pada masa usia 50-80 tahun wanita mengalami pengurangan hormon estrogen yang signifikan. Pengurangan hormon estrogen menyebabkan penurunan produksi cairan sinovial pada sendi (Price \& Wilson, 2005). Hasil perhitungan dalam penelitian ini diperkuat oleh penelitian Fransen et al., (2011) yang menunjukkan bahwa angka kejadian OA lebih besar terjadi pada perempuan dan prevalensi OA bersifat dependen terhadap usia. Menurut penulis, faktor mendasar yang menyebabkan OA lutut banyak terjadi pada perempuan adalah kejadian menopause yang menyebabkan penurunan kadar hormon estrogen secara drastis, sementara pada laki-laki kadar hormon estrogen menurun secara perlahan. Hormon estrogen berperan dalam pembentukan tulang, bekerja dengan vitamin $\mathrm{D}$, kalsium, dan hormon lainnya untuk secara efektif memecah dan membangun kembali tulang sesuai proses salami tubuh. Status pendidikan memengaruhi kesempatan memperoleh informasi mengenai penatalaksanaan penyakit (Potter \& Perry, 2005). Tingkat pengetahuan lansia yang rendah dapat meningkatkan kejadian nyeri sendi karena tingkat pendidikan yang rendah menimbulkanketerbatasan dalam memperoleh pengetahuan untuk mencegah, ptoteksi dini, dan penatalaksanaan nyeri sendi yang tepat guna meningkatkan derajat kesehatan lansia.

Seluruh responden penelitian yang berjumlah 24 orang mengalami nyeri sendi dengan skala nyeri yang bervariasi dari skala sedang hingga berat terkontrol. Hal ini juga sesuai dengan manifestasi klinis OA yang dikemukakan Subcommittee American College of Rheumatology (ACR), jika memenuhi tiga dari enam hal berikut yaitu: usia $>50$ tahun, kaku sendi $<30$ menit, krepitus, nyeri tulang, pembengkakan tulang (bone enlargement) (Altman et al., 2011). Pendapat ini diperkuat oleh Bales (2008), yang mengatakan bahwa keluhan utama yang selalu muncul pada penderita dengan OA adalah nyeri sendi. Nyeri sendi muncul dengan adanya hambatan pada sendi saat dilakukan gerakan. Selain nyeri sendi, lansia juga mengatakan mengalami kaku pada sendi yang bertambah pada malam hari dan ketika peneliti melakukan pemeriksaan fisik, pada tulang lutut responden penelitian juga menimbulkan suara krepitus serta nyeri pada tulang. Beberapa tanda gejala tersebut membuktikan bahwa manifestasi klinis OA berdasarkan ACR melalui tindakan pemeriksaan fisik nyata terjadi pada penderita OA.

Dengan keberadaan nyeri akibat OA lutut ini, maka lansia yang menderita membatasi pergerakan pada bagian yang nyeri (Sharma \& Berenbaum, 2013).Pembatasan gerak pada sendi dapat menyebabkan kekakuan atau atropi otot sendi yang lama kelamaan dapat menghentikan secara permanen fungsional sendi tersebut. Penghentian keaktifan sendi ini membatasi aktivitas fisik lansia, lansia mengalami penurunan dari quality of life (Hopman-Rock et al., 2007). Hal inilah yang dilakukan oleh responden kelompok kontrol yaitu dengan beristirahat selama nyeri sendi muncul. Padahal aktivitas fisik 
Vivi Meliana Sitinjak : Pengaruh Senam Rematik terhadap Perubahan Skala nyeri

berupa senam dapat mengurangi sensasi nyeri pada persendian lebih baik daripada hanya dengan beristirahat (Mentes et al., 2010). Penelitian sebelumnya oleh Bennel et al., (2012) menjelaskan aktivitas fisik dapat meningkatkan fungsional fisik lansia dan kualitas hidup lansia. Jika lansia enggan mengikuti kegiatan senam, justru dapat menyebabkan kekakuan tulang dan sendi yang menjadi penyebab timbulnya nyeri persendian pada lansia (Michael \& Kelley, 2010).

Hasil uji Paired $T$ Testdidapatkan $p$ value kelompok perlakuan sebesar 0,000 dan $p$ value kelompok kontrol sebesar 0,017. Hasil $p$ value kedua kelompok $<0,005$ yang berarti ada perubahan skala nyeri sendi pada kedua kelompok berupa penurunan skala nyeri sendi, meskipun tidak diberikan senam rematik tetapi mean skala nyeri sendi kelompok kontrol juga menurun dengan nilai penurunan yang lebih rendah dibandingkan kelompok kontrol. Kelompok kontrol yang tidak diberikan senam rematik tidak mengalami penurunan skala nyeri sendi yang signifikan dengan ratarata penurunan hanya sebesar 0,417 karena responden diminta untuk beraktivitas seperti biasa dan beristirahat tanpa menggunakan obat-obatan. Menurut penelitian Bender et al., (2010), terapi fisik dapat meningkatkan level beta endorfin dalam tubuh.Istirahat mungkin meredakan nyeri tetapi hanya menurunkan skala nyeri dengan rentang penurunan yang kecil karena istirahat seperti tidur atau duduk diam tanpa pergerakan tidak merangsang pelepasan endorfin. Pergerakan seperti senam rematik dan olahraga memiliki dampak yang lebih baik bagi penderita nyeri sendi dibandingkan dengan beristirahat. Penurunan skala nyeri sendi pada kelompok kontrol diduga sebagai efek istirahat yang dilakukan dan keterbatasan peneliti yang tidak mampu mengontrol secara ketat penggunaan koyo yang dilakukan oleh lansia kelompok kontrol. Hasil uji Independent T Test pada posttest antara kelompok perlakuan dan kelompok kontrol didapatkan p-value sebesar 0,000. Hasil $p<0,005$ berarti terdapat perbedaan mean skala nyeri sendi yang bermakna antara kelompok perlakuan yang diberikan intervensi senam rematik dan kelompok kontrol yang tidak diberikan senam rematik, dimana skala nyeri sendi posttest dengan senam rematik $($ mean $=4,92)$ lebih rendah daripada tidak diberikan senam rematik (mean $=6,58)$.

Salah satu tanda dan gejala dari OA lutut adalah nyeri sendi lutut. Nyeri yang terus menerus terjadi akan melemahkan sendi (Price \& Wilson, 2005). Menurut the gate control theory (teori kontrol pintu), upaya menutup pertahanan untuk mencegah pelepasan substansi $\mathrm{C}$ dan substansi $\mathrm{P}$ yang merupakan pentransmisi nyeri adalah dengan menghasilkan masukan dominan serabut beta-A yang akan menghambat nyeri, upaya ini dapat dilakukan salah satunya dengan latihan fisik (Muttaqin, 2008). Menurut Hunter \& Felix (2010), latihan fisik dapat meningkatkan sirkulasi darah dan merangsang peningkatan enzim-enzim tubuh yang berperan dalam proses oksigenasi jaringan. Dalam American College of Sports Medicine dan American Heart Association juga dikatakan bahwa aktivitas fisik sangat direkomendasikan bagi lansia karena secara langsung dapat memperbaiki kesehatan lansia yaitu dengan meningkatkan mobilitas sendi, memperkuat otot yang menyokong dan melindungi sendi, mengurangi nyeri, dan mengurangi kaku sendi (Nelson et al., 2007).

Nyeri sendi pada penderita OA termasuk dalam kategori nyeri somatik dalam dimana reseptor nyeri ini terletak pada otot dan tulang serta penyokong tubuh lainnya. Tubuh memiliki neuromodulator alami yang dapat menghambat transmisi impuls nyeri salah satunya adalah beta-endorfin. Menurut American Geriatric Society olahraga seperti senam sebanyak tiga kali seminggu secara signifikan memperbaiki kesehatan pasienpasien arthritis termasuk OA. Olahraga senam dapat menstimulasi peningkatan pelepasan hormon endorfin. Endorfin memberikan efek analgesia dengan memblokir proses pelepasan substansi $p$ dari neuron sensorik sehingga proses transmisi impuls nyeri di medula spinalis menjadi terhambat dan sensasi nyeri menjadi berkurang.

Nyeri ketika melakukan aktivitas seharihari, pembengkakan pada sendi, kaku sendi, kelelahan, bahkan kelainan bentuk tubuh sering dialami orang yang menderita rematik, fokus penanganan penderita rematik adalah mengontrol rasa nyeri, mengurangi kerusakan sendi, serta mempertahankan fungsi kualitas gerak. Pada orang yang normal gerakan menjadi terjaga karena dapat bergerak aktif 
Vivi Meliana Sitinjak : Pengaruh Senam Rematik terhadap Perubahan Skala nyeri

sementara pada penderita rematik, terjadi kesulitan untuk menggerakkan tubuh karena nyeri. Bila tidak digerakkan dalam jangka waktu yang lama sendi menjadi lengket dan sama sekali tidak bisa digerakkan. Masalah ini yang harus dicegah dengan melakukan olah fisik seperti senam rematik karena latihan sendi yang teratur merupakan salah satu upaya menjaga kebugaran dan kesehatan tubuh lansia.Jika lansia enggan mengikuti kegiatan senam, justru dapat menyebabkan kekakuan tulang dan sendi yang menjadi penyebab timbulnya nyeri persendian pada lansia.Senam rematik merupakan suatu aktivitas olahraga bagi lansia yang membantu tubuh tetap lentur dan juga memperkuat otot dan ligamen yang menstabilkan sendi. Kapasitas konsentrasi senam rematik terletak pada gerakan sendi yang meregangkan dan menguatkan otot, karena otot-otot itulah yang membantu sendi untuk menopang tubuh. Senam yang diberikan kepada lansia tidak perlu terlalu berat, cukup dengan gerakan pelan dan dapat diikuti oleh lansia serta mengandung unsur pemanasan dan pendinginan. Di dalam senam rematik untuk lansia sudah mengandung unsur yang melibatkan kontraksi otot yang dinamis dan melibatkan banyak otot yang dapat meningkatkan volume curah jantung. Senam rematik memiliki 6 tahapan yaitu latihan pernapasan, latihan kekuatan, latihan pemanasan, latihan persendian, latihan kardio, dan peregangan.

Kelebihan senam rematik tidak hanya pada gerakan yang aktif, berulang, dan mudah dilakukan. Sesudah melakukan gerakan senam rematik lansia terlihat rileks, nyaman, dan menunjukkan ekspresi wajah tersenyum. Menurut penelitian Bender et al., (2007), latihan atau senam dalam hal ini termasuk senam rematik memiliki dampak psikologis langsung yakni membantu memberi perasaan santai, mengurangi ketegangan, dan meningkatkan perasaan senang karena saat senam kelenjar pituitari menambah produksi atau meningkatkan level betaendorfin. Hal ini didukung oleh Nursalam dan Kurniawati (2014), selain produksi beta-endorfin, senam juga meningkatkan aktivitas penyaluran saraf didalam otak yaitu peningkatan neurotransmitter parasimpatis (norepinephrine, dopamine, dan serotonin). Peningkatan konsentrasi beta-endorfindi dalam darah dan saraf parasimpatis menurunkan denyut jantung dan denyut nadi sehingga menyebabkan nyeri yang memunculkan kekakuan sendi berkurang.

\section{Simpulan}

Kesimpulan yang dapat diperoleh dalam penelitian ini adalah ada pengaruh senam rematik terhadap perubahan skala nyeri sendi lanjut usia dengan OA lutut di Panti Werdha Sinar Abadi Kota Singkawang Tahun 2016. Hasil ini sesuai dengan paired t test pada kelompok perlakuan yang menunjukkan nilai $p$-value sebesar 0,000 dan kelompok kontrol $p$-value sebesar 0,017 ( $p<0,05)$. Hasil Independen $t$ test untuk posttest kelompok perlakuan dan kelompok kontrol menunjukkan $p$-value sebesar $0,000(\mathrm{p}<0,05)$ yang berarti terdapat perbedaan mean skala nyeri sendi yang bermakna antara kelompok perlakuan yang diberikan intervensi senam rematik dan kelompok kontrol yang tidak diberikan senam rematik, dimana skala nyeri sendi dengan senam rematik lebih rendah daripada skala nyeri yang tidak diberikan senam rematik.

\section{Daftar Pustaka}

Altman, R., et al. (2011). The american college of rheumatology criteria for the classification and reporting of osteoarthritis of the hip. Arthritis \& Rheumatism, p.505-514.

American Geriatric Society. (2005). Exercise prescription for older adults with osteoarthritis pain: consensus practice recommendation. Journal Of American Geriatric Society. p.819.

Arden, N., \& Nevitt, M.C. (2006). Osteoarthritis: Epidemiology. Best Practice \& Research Clinical Rheumatology, 20(1), p.3-25.

Arissa, M.I. (2013). Pola distribusi kasus osteoarthritis di RSU Dokter Soedarso Pontianak periode 1 Januari 2008 - 31 Desember 2009. Jurnal Mahasiswa PSPD FK Universitas Tanjungpura, 1(1), h.1-16.

Badan Pusat Statistik Indonesia. (2015). Available At : https://www.bps.go.id/ 
Vivi Meliana Sitinjak : Pengaruh Senam Rematik terhadap Perubahan Skala nyeri

(Diperoleh pada tanggal 01 Oktober 2015)

Bales, P. (2008). Osteoarthritis: Preventing and healing without drugs. Prometheus Books.

Bender, T., Nagy, G., Barna, I., Tefner, I., Kádas, É., \& Géher, P. (2010). The effect of physical therapy on beta-endorphin levels. European Journal Of Applied Physiology, 100(4), p.371-382.

Capezuti, E., et al. (2008). Evidence-based geriatric nursing protocols for best practice. Pain management horgas \& yoon (3rd Ed.). USA: Springer publishing company.

DeWaters, T., Faut-Callahan, M., McCann, J.J., Paice, J.A., Fogg, L., Hollinger-Smith, L., ..., \& Stanaitis, H. (2008). Comparison of self reported pain and the PAINAD scale in hospitalized cognitively impaired and intact older adults after hip fracture surgery. Orthopaedic Nursing, 27(1), p.21-28.

Efendi, F., \& Makhfudli. (2009). Keperawatan kesehatan komunitas: Teori dan praktik dalam keperawatan. Jakarta: Salemba Medika. h.241-246.

Eliopoulos, C. (2013). Gerontological Nursing (8th Ed.). Lippincott Williams \& Wilkins, p.35.

Felson, T., \& Schaible, H-G. (2010). Pain in osteoarthritis. Wiley-Blackwell A John Wiley \& Sons; p.240-243.

Fransen, M., Bridgett, L., March, L., Hoy, D., Penserga, E., \& Brooks, P. (2011). The epidemiology of osteoarthritis in Asia. International journal of rheumatic diseases, 14(2), p.113-121.

Hardywinoto, S. (2005). Panduan gerontologi: Tinjauan dari berbagai aspek. Jakarta: Penerbit PT Gramedia.

Heri, K. (2014). Pengaruh senam rematik terhadap nyeri sendi pada lansia di Panti Sosial Tresna Werdha Budimulia 04 Margaguna Jakarta Selatan. Jurnal Mahasiswa Program Keperawatan Universitas Esa Unggul, 1(1), h.1-10.
Hochberg, M., et al. (2012). American college of rheumatology 2012 recommendations for the use of nonpharmacologic and pharmacologic therapies in osteoarthritis of the hand, hip, and knee. Arthritis Care \& Research, 64(4), p.465-474.

Hopman-Rock, Kraaimaat, M.F.W., \& Bijlsma, J.W.J. (2013). Quality of life in elderly subjects with pain in the hip or knee. Quality of Life Research, 6(1), p.67-76.

Hunter, D.J., \& Feliz, E. (2010). Exercise and osteoarthritis. Journal Of Anatomy, 214(2), p.197-207.

Isbagio, H. (2005). Pendekatan diagnostik penyakit rematik. Subbagian Reumatologi. Bagian Ilmu Penyakit Dalam Fakultas Kedokteran Universitas Indonesia/ Rumah Sakit Dr. Cipto Mangunkusumo. Jakarta: Cermin Dunia Kedokteran, h.12.26.

Khairani, Y., Husni, E., \& Aryanty, N. (2012). Hubungan umur, jenis kelamin, IMT, dan aktivitas fisik dengan kejadian osteoarthritis lutut (Skripsi), h.1-8.

Klieman, L., et al. (2011). Exercise and older adults. Current Cardiovascular Risk Reports, p.335-339.

Litwic, A., Edwards, M.H., Dennison, E.M., \& Cooper, C. (2013). Epidemiology and burden of osteoarthritis. British Medical Bulletin, lds 038 .

Maharani, E.P., (2010). Faktor-faktor risiko oklsteoartritis lutut (Studi kasus di Rumah Sakit Dokter Kariadi Semarang. Universitas Diponegoro, Semarang (Tesis), h.1-8.

Mentes, J.C., \& Egan, B.A. (2010). Benefits of physical activity for knee osteoarthritis: A brief review. Journal of Gerontological Nursing, 36(9), p.9-14.

Michael, L.T., \& Kelley, T. (2010). Nonsurgical management of osteoarthritis of the knee. Journal of the American Academy of Physician Assistants, 19(1), p.26-32.

Mirza, Y. (2012). Pemberian latihan contract 
Vivi Meliana Sitinjak : Pengaruh Senam Rematik terhadap Perubahan Skala nyeri

relax dan mobilisasi sendi untuk peningkatan lingkup gerak sendi flexi shoulder pada lansia. Jurnal Universitas Muhammadiyah Surakarta (Skripsi), h.1-15.

Muchid, dkk. (2006). Pharmaceutical care untuk pasien dengan penyait arthritis rematik. Direktorat Bina Farmasi Komunitas dan Klinik Ditjen Bina Kefarmasian dan Alat Kesehatan Dinas Kesehatan.

Muslihah, Y.M, (2014). Gambaran osteoartritis genu pada pasien di RSUP Fatmawati Jakarta Tahun 2012-2013 (Skripsi), h.1-15.

Muttaqin, A. (2008). Asuhan keperawatan klien dengan gangguan sistem persarafan. Jakarta: Salemba Medika, h.504-508.

Nelson, M.E., et al. (2010). Physical activity and public health in older adults: Recommendation from the American College of Sports Medicine and the American Heart Association. Circulation, 28(6), 339-340.

Nurhidayah, K. (2012). Pengaruh senam rematik terhadap aktifitas fungsional lansia di komunitas senam lansia Wilayah Kelurahan Nusukan Banjarsari Surakarta, Muhammadiyah Surakarta, Solo (Skripsi), h. $1-12$.

Nursalam \& Kurniawati, N. (2007). Asuhan keperawatan pada pasien terinfeksi hiv aids, edisi1. Jakarta : Salemba medika, h. 61-65.

Potter, P.A., \& Perry, A.G. (2005). Buku ajar fundamental keperawatan: Konsep, proses, dan praktik. Jakarta: EGC, p.1376.

Price, S.A., \& Wilson, L.M. (2005). Patofisiologi: Konsep klinis proses-proses penyakit (Edisi 4). Jakarta: Penerbit Buku Kedokteran EGC, h.1218-1222.

Riskesdas. (2013). Available At : http:// labdata.litbang.depkes.go.id/riset-badanlitbangkes/menu-riskesnas/menu-riskesdas (Diperoleh pada tanggal 12 Desember 2015).

Roddy, E., Zhang, W., \& Doherty, M. (2011). Aerobic Walking Or Strengthening Exercise
For Osteoarthritis Of The Knee? A Systematic Review. Annals Of The Rheumatic Diseases. 64(4), p.544-548.

Roman-Blas, J.A., Castañeda, S., Largo, R., \& Herrero-Beaumont, G. (2013). Osteoarthritis associated with estrogen deficiency. Arthritis Research \& Therapy, 11(5), p.1-14.

Santoso, H., \& Ismail, H. Memahami Krisis Lanjut Usia. BPK: Gunung Mulia. 2009, h.3644.

Sharma, L., \& Berenbaum, F. (2013). Osteoarthritis: A companion to rheumatology. Elsevier Health Sciences, p.15-20.

Smeltzer, S.C., \& Bare, B.G. (2005). Buku ajar keperawatan medikal bedah Brunner dan Suddarth, Volume 1 dan Volume 3, Edisi 8. Jakarta: EGC, p.382-383.

Stanley, M. (2007). Buku ajar keperawatan gerontik (Gerontological nursing: A health promotion or protection approach). Jakarta: EGC.

Stevenson, J.D., \& Richard Roach. (2012). The benefits and barriers to physical activity and lifestyle interventions for osteoarthritis affecting the adult knee. Journal of Orthopaedic Surgery And Research. p.1-7.

Tamsuri, A. (2007). Konsep dan penatalaksanaan nyeri. Penerbit Buku Kedokteran. Jakarta: EGC.

Widyastuti, Y. (2008). Pengaruh pendidikan kesehatan tentang penyakit osteoarthtritis terhadap tingkat pengetahuan dan sikap pasien osteoarthtritis di Wilayah Kerja Puskesmas Gondangrejo Karanganyar, (Skripsi), h.1-8.

World Health Organization (WHO). (2011). Available At : http://www.who.int/en/ (Diperoleh pada tanggal 10 oktober 2015).

Yatim F. (2006). Penyakit tulang dan persendian (artritis atau artralgia), Edisi. 1. Jakarta: Pustaka Populer Obor. h. 26-32, 111115. 